\title{
UVODNIK
}

\section{MEDKULTURNOST V IZOBRAŽEVANJU ODRASLIH}

V času, ko smo pripravljali to številko Andragoških spoznanj, se je okrepil vojni konflikt v Siriji, nekatere druge države sveta, kot so Afganistan, Irak, Sudan, Sierra Leone ..., pa prav tako pretresajo vojni spopadi in kršitve človekovih pravic, ki so prisilili njihove prebivalce, da so prebegnili v druge države in si tako rešili življenje. Nekateri izmed njih so svoje zatočišče našli tudi v Sloveniji, nekateri pa se v našo državo želijo preseliti iz ekonomskih razlogov. Pravzaprav so se že v prejšnjih zgodovinskih obdobjih morali številni ljudje prisilno preseljevati, med drugimi je bil tudi Einstein še pred začetkom druge svetovne vojne prisiljen pred nacizmom v Nemčiji prebegniti v Združene države Amerike, nekateri pa se v druge države preseljujejo iz ekonomskih razlogov, a tudi vse preselitve iz ekonomskih razlogov niso popolnoma prostovoljne. Pogosto se ljudje preseljujejo v druge države tudi v izobraževalne namene, da bi imeli boljše možnosti za izobraževanje in usposabljanje, kot na primer dvakratna Nobelova nagrajenka Marie Curie, ki se je iz rodne Poljske preselila v Francijo, da bi imela boljše pogoje za študij in nadgrajevanje znanja. Iz navedenih primerov je razvidno, da migranti in migrantke za družbo pomenijo potencial in ne breme, saj prinašajo koristi za prebivalce in prebivalke države sprejema na več družbenih področjih, zlasti na družbeno-kulturnem in ekonomskem, če jim država sprejema zagotovi uspešno vključevanje na trg dela. Ob tem se moramo zavedati, da migranti niso homogena skupina, temveč se med seboj razlikujejo, zato ne smemo posploševati lastnosti enega posameznika ali posameznice na vso skupino, kar je ena izmed opredelitev stereotipa (več o tem Ule, 2004). To pomeni, da če je med tisoči migrantov in migrantk kakšen, ki je kadarkoli storil kakšno kriminalno dejanje, ne smemo posploševati, da so vsi migranti zakrivili kriminalna dejanja, podobno pa velja tudi za večinsko prebivalstvo.

Ljudje, ki se k nam priselijo začasno ali trajno, s seboj v državo sprejema prinašajo med drugim tudi znanje, kompetence, sposobnosti, veščine in različne izkušnje. Pomembno je, da se migranti in migrantke čim prej vključijo v sistem vzgoje in izobraževanja, v vrtce, osnovne in srednje šole, univerze in v izobraževanje odraslih. Če se ne vključujejo v sfero vzgoje in izobraževanja, se težje integrirajo v širšo družbo. Prav izobraževanje odraslih pa migrantom in migrantkam zagotavlja lažjo vključitev na trg dela in jim s tem pomaga uresničiti pravico do dela, ki je temeljna človekova pravica (več Vrečer, 2007), saj ljudem zagotavlja preživetje. 
Integracijske strategije zagotavljajo win-win situacijo za migrante in državo sprejema, saj na številnih področjih pridobijo tako ljudje, ki so se priselili, kot družba sprejema, ta namreč dobi tudi nove davkoplačevalce in davkoplačevalke, če jim seveda omogoči dostop do zaposlovanja, poleg tega pa migranti in migrantke prinašajo možnost za socialno in kulturno izmenjavo. Ob integraciji tako nastajajo »učeče se kulture«, saj gre za dvosmerne procese, ko se migrantke in migranti učijo od prebivalk in prebivalcev države sprejema in slednji od migrantov in migrantk (Vrečer, 2011).

Vendar pa morajo nekateri migranti in migrantke pri vključevanju v sistem vzgoje in izobraževanja ter širšo družbo premagovati določene težave, tudi med nekaterimi Slovenci in Slovenkami namreč prevladuje stereotip, da so med migranti in migrantkami zlasti tisti z nižjo izobrazbo, podatki Zavoda Republike Slovenije za zaposlovanje pa dokazujejo, da so bili leta 2012 med migranti in migrantkami brez slovenskega državljanstva z veljavnim delovnim dovoljenjem številčno najbolj zastopani tisti s srednješolsko izobrazbo, kot je zapisano tudi v Strategiji vključevanja priseljencev v izobraževanje odraslih $2013 .{ }^{1}$

Raziskava Andragoškega centra Slovenije iz leta 2008 je pokazala, da je približno 40 odstotkov migrantov in migrantk v Sloveniji na delovnem mestu že vsaj enkrat doživelo diskriminacijo zaradi svoje etnične pripadnosti (glej Vrečer, Možina, Svetina, Žalec in Javrh, 2008). De Vries in Wolbers (2004, v Impact of ..., 2008) navajata rezultate raziskave, po kateri so imeli osipniki migranti, ko so se zaposlili, nižje dohodke kot večinsko prebivalstvo, manjše možnosti, da pridobijo stalno zaposlitev, ter službe na manj uglednih delovnih mestih (ne kot menedžerji ali na drugih vodilnih delovnih mestih). Raziskava projekta Included (Impact of ..., 2008) pa dokazuje, da so se bili nekateri migranti in migrantke prisiljeni zaposliti na nižjem delovnem mestu, kot jim je zagotavljala njihova izobrazbena raven. Prav je, da se tudi andragogika bolj angažira na tem področju, da pomaga rešiti nekaj tovrstnih družbenih problemov, ker so migracije izziv tudi za andragogiko, saj krepi izobraževanje odraslih, v katerega se vključujejo tudi migranti in migrantke.

Tematsko številko Andragoških spoznanj o medkulturnosti v izobraževanju odraslih začenja članek Klare Skubic Ermenc, ki opisuje rezultate pilotne raziskave o izkušnjah učiteljev in učiteljic v poklicnem in strokovnem izobraževanju z dijaki in dijakinjami migrantskega ozadja. Avtorica meni, da dijakov in dijakinj z migrantskim ozadjem v izobraževalnem sistemu ne bi smeli obravnavati kot dijake s posebnimi potrebami; zdaj so namreč nekateri zaradi slabšega znanja slovenskega jezika dojeti kot skupina otrok, ki so prikrajšani, kar je sporno z vidika tako medkulturno kot inkluzivno naravnane pedagogike.

$\mathrm{V}$ preteklosti je večina znanstvenih raziskav o migracijah namenjala pozornost v glavnem moškim. Članek Klare Kožar Rosulnik potrjuje, da migracije zajemajo tudi ženske, samo da jih raziskave do zdaj niso obravnavale. Migracije se pri tem kažejo kot spolno

\footnotetext{
1 Strokovni svet za izobraževanje odraslih (SSIO) pri ministrstvu za izobraževanje, znanost in šport (MIZŠ) je dal na 71. seji SSIO dne 18. 4. 2013 pozitivno mnenje k Strategiji vključevanja priseljencev v izobraževanje odraslih (2013). Strategije MIZŠ še ni uradno potrdilo, čeprav je rok za udejanjanje prvega akcijskega načrta že potekel, v manjšem obsegu pa se njene vsebine že uresničujejo.
} 
zaznamovan proces. Spremembe, ki jih prinašajo migracije, doživljajo moški in ženske različno, a tudi ženske v migracijah ohranjajo vlogo agensa, ki z zavestno odločitvijo za spremembo v življenju prevzame odgovornost in nadzor nad svojim življenjem.

$\mathrm{V}$ migracijskih procesih se posamezniki in posameznice učijo, med drugim tudi z izkustvenim učenjem. Model tranzicijskega učenja ponuja učinkovito orodje za analizo izkustvenega učenja v migracijskih procesih. V svojem članku Petra Jejčič ugotavlja, kako se posamezniki in posameznice ob doživljanju migracijskih izkušenj učijo in katere strategije pri tem uporabljajo: strategijo prilagoditve, rasti, razlikovanja kot tudi strategijo upora. Kljub temu pa se moramo zavedati, kot sva avtorici uvoda že omenili, da migranti in migrantke niso homogena skupina, temveč heterogena, iz tega pa lahko sklepamo, da se tudi načini učenja med posameznimi migranti in posameznimi migrantkami lahko razlikujejo.

Članek Beate Schmidt-Behlau obravnava prispevek staroselcev in staroselk v Latinski Ameriki, ki pomembno soustvarjajo tamkajšnjo multikulturno družbo. Avtorica predstavi razvoj medkulturnega modela dvojezičnega izobraževanja. Učenje jezika staroselcev in staroselk zelo pripomore k ohranjanju njihovih kultur. Članek poudarja vlogo medkulturnega učenja in potencial, ki ga to prinaša tudi za opolnomočenje ljudi ter transformacijo, temelječo na dialogu med staroselskimi in zahodnimi kulturami, ki se dogaja v procesu izobraževanja in ozaveščanja o razvojnem delu.

Za uspešen medkulturni dialog je pomembno, da imajo pripadniki in pripadnice vseh kultur, ki sodelujejo v njem, medkulturne kompetence, empatija pa je po mnenju avtorice članka Natalije Vrečer najpomembnejša medkulturna kompetenca, saj je pogosto pogoj za sočutje, spoštovanje ... Če smo človeka sposobni videti iz njegove oziroma njene perspektive, kar je stopnja v razvoju izkušnje empatije, potem ga tudi laže razumemo. Avtorica $\mathrm{v}$ članku opisuje izvor besede empatija, njen poudarjeni pomen $\mathrm{v}$ glavnih religijah sveta, nevroznanstveno razlago empatije, vlogo empatije v izobraževanju odraslih, primere nekaterih dobrih praks izobraževalnih programov za krepitev empatije v svetu in doma.

Izvirnim znanstvenim člankom tudi v tej tematski številki sledijo strokovnimi prispevki, $\mathrm{v}$ katerih predstavljamo uresničene projekte s področja medkulturnega učenja in dva intervjuja s ključnima akterkama medkulturnega dialoga. V članku Tine Baloh »Spodbujanje medkulturnega dialoga « je predstavljen projekt »Vklopi se«, ki se osredotoča na migrante. Namenjen je spodbujanju sodelovanja med domačim prebivalstvom in državljani tretjih držav na najrazličnejših področjih vsakdanjega življenja kot tudi ozaveščanju javnosti o pomenu strpnosti in medkulturnega dialoga ter promociji etnične raznolikosti. Sledi intervju z Eniso Murgić, profesorico angleščine, udeleženko programa Začetna integracija priseljencev (ZIP), ki se je v Slovenijo priselila iz Velike Kladuše v Bosni in Hercegovini. Intervju je opravila Maja Regina, zaposlena na RIC Novo Mesto. Katja Lihtenvalner pa se je pogovarjala z Lauretto Macauley, predsednico grškega Združenja afriških žensk, in ob tem prinaša razmislek o migracijskih izkušnjah v Evropski uniji. V rubriki »Poročila, odmevi, ocene« Zaira Vidau in Norina Bogatec predstavljata projekt »EDUKA - vzgajati k različnosti«, cilj katerega je oblikovanje sprejemajoče multikulturne družbe. Peter 
Beltram pa predstavlja novosti v letu 2013 sprejete Resolucije o nacionalnem programu izobraževanja odraslih za obdobje 2013-2020 (ReNPIO 2013-2020). Na koncu revije sledita še recenziji dveh knjig izpod peresa Barbare Zorman in Nataše Rijavec Klobučar. Prva recenzira knjigo Matevža Rudolfa »Ko beseda podobo najde. Slovenska literatura in film v teoriji in praksi (1984-2012) «, ki sta jo leta 2013 izdala Slovenska kinoteka in UMco, druga recenzentka pa knjigo Dragana Petrovca »Nasilje pod masko«, ki je letos izšla pri Založbi Sanje.

\section{LITERATURA}

De Vries, M. in Wolbers, M. (2004). Ethnic variation in labour market outcomes among school-leavers in the Netherlands: the role of educational qualifications and social background. Journal of youth studies, 7, 3-18.

Impact of Education on Employment Opportunities. Literature review interim report. Workpackage 10. Includ-ed. Strategies for Inclusion and social cohesion in Europe from education. FP6 European Commission (2006-2011). (2008). Barcelona: CREA, University of Barcelona.

Ule, M. (2004). Socialna psihologija. Ljubljana: Fakulteta za družbene vede.

Vrečer, N. (2007). Integracija kot človekova pravica. Prisilni priseljenci iz Bosne in Hercegovine v Sloveniji. Ljubljana: Založba ZRC SAZU in Andragoški center Slovenije.

Vrečer, N. (2011). Učeče kulture: večkulturno izobraževanje v primerjalni perspektivi. IB revija, 45(1/2), 19-27.

Vrečer, N., Možina, E., Svetina, M., Žalec, N. in Javrh, P. (2008). Izobraževanje in usposabljanje migrantov v Sloveniji. Raziskovalno poročilo. Ljubljana: Andragoški center Slovenije.

Natalija Vrečer in Maja Mezgec ${ }^{2}$

2 Stališča avtorjev in avtoric v člankih te tematske številke Andragoških spoznanj niso vedno tudi mnenja gostujočih urednic. 